\title{
Teacher Training in Turkey From Historical Perspective*
}

\author{
İsa Korkmaz \\ Necmettin Erbakan University, Konya, Turkey
}

\begin{abstract}
A major educational debate today concerns how to recruit and prepare teachers all over the world. In other words, policy makers in education attempt to figure out high quality initial teacher training programs. Similarly, one of the main controversial issues in Turkey is who is going to be a teacher. Alternative programs for recruiting and preparing teacher have been devised, discussed, and applied. However, these programs have been implemented not because of results of research comparing the effectiveness of teachers from different types of preparation backgrounds but the program has been implemented because of current government policies. Since Turkish education system is centralized, the Ministry of National Education appoints all novice teachers according to their scores in the nationwide state examination conducted by state for state employee. Teachers in Turkey are recruited from two sources: One is education faculty graduates to be teacher at elementary, middle and high schools. The other source is different faculty graduates such as faculty of literature, art, science, theology, and etc. to teacher, particularly, at high schools. The aim of this study is to review teacher training and recruitment in Turkey from 1923 to present. The method of this study is to analyze printed document and changing policies and reforms about training and recruiting teachers in Turkish schools. During the Republic Era teacher training policies and applications have been changed several times radically. In addition, the effectiveness of factors on teacher training policies in terms of year and theory is indicated.
\end{abstract}

Keywords: teacher training, recruiting, Turkish education system

\section{Introduction}

The most important factor affecting student learning is the teacher. Although students' achievements are results of effectiveness of school, curriculum, teacher, and their home environment; a teacher can have a powerful effect on student's achievement regardless of quality of school and home environment. Teacher level factors consist of instructional strategies, classroom management, and classroom curriculum design. In fact, teacher level factors are related to the quality of teacher performance in the instructional settings. Qualities of teacher effectiveness are resulted of his/her preparation, personality, and practice. It is recognized by all educators that a teacher's pedagogical background and professional preparation are prerequisites of effective teaching. Although an effective teacher is an important factor on students' academic achievement, a key question is how to find, recruit, and prepare qualified teachers.

\footnotetext{
* Acknowledgments: This study was supported by Necmettin Erbakan University Foundation of Scientific Research Project (BAP number: 141610072).

İsa Korkmaz, Ph.D., Professor of Curriculum and Instruction, Ahmet Kelesoglu Education Faculty, Necmettin Erbakan University.
} 
The results of several studies indicate that teachers are the most influential factor on student achievement. Effective teachers do make an extraordinary and lasting impact on the lives of student. Moreover, as a result of meta-analysis, it was found that effective teachers have a profound influence on student achievement, and ineffective teachers do not (Marzano, 2003). An effective teacher pays attention to students' social and emotional growth as well as offers high quality academic and cognitive support (Scherer, 2012). Sanders and Horn (1994) found that a student with a weak teacher for three straight years, on average scores $50 \%$ points was behind a similar student within a strong teacher for those years. The best teachers know how to respond to students' choices and to integrate their interests into a curriculum with high standards. Teaching student their interests automatically facilitates differentiated instruction and leads to improved test scores (R. N. Caine \& G. Caine, 2006).

Qualities of teacher effectiveness are the outcome of his/her preparation, personality, and practice. It is recognized by all educators that a teacher's pedagogical background and professional preparation are prerequisites of effective teaching. According to the related research review, a teacher's formal pedagogical preparation has been shown to have a positive effect on student achievement. On the other hand, uncertified teachers and out of field teachers achieve far less with students than teachers with proper in-field certification (Stronge, 2002). In fact, there is no doubt that an effective teacher is an important factor on students' academic achievement. However, a key question is how to find, recruit, and prepare qualified teachers.

Teacher training programs in Turkey has been changed in terms of year and related to school levels. Although the role of teacher has been appraised to develop society, it has not been figured out how to train prospective teachers in the Turkish education system. In order to look at teacher training and recruiting, it should be started from school level because each school level has different requirements of teacher training. In fact, teacher training programs of Turkey is going to be explained in three school levels. First of all, it is necessary to give brief information about recent Turkish school structure. Education Reform Bill was enacted by The Turkish Great National Assembly on April 1, 2012. According to the Education Act, compulsory education became 12 years. K-12 school system in Turkey is called four plus four plus four publicly. That means that the first four is elementary school, the second is middle school, and the third is high school.

\section{Elementary School Teacher Training}

Although The Republic of Turkey was founded in 1923, teacher training schools was opened 1846 during the Ottoman Era. About 1870, Ottoman Empire started to westernize policy into mainly army and education systems. Turkish school system began to reform like western school system. New schools were to build nationwide and people were encouraged to send their kids to schools because formal education was not considered as important in people's daily life. When the Republic of Turkey was founded, there were about 20 teacher training schools 13 of which for boys and other seven for girls (YOK, 1998). Until 1924, those schools' education year was four year after fifth grade elementary school. In 1924, the school was adapted to five year and in 1932-1933 six year educational programs for elementary teacher training. The school system was planned three years for middle school and three years for high school after fifth grade elementary school.

Policy makers of the new republic realized the power of education for social and economic development. On the other hand, the main goal of young state was to obtain western civilization as fast as possible. Therefore, well 
skilled and educated human capital was needed urgently. Since illiteracy was very high among Turkish society, especially rural areas, Turkish government tried to apply several polies for fighting illiteracy and poverty. All policies started in rural areas and social change also started as grassroots movement. It was the duty of education to change and improve peoples' economic and social life. The main part of this movement was to change alphabet from Arabic to Latin in 1928. Although Turkish government attempted several developmental policies, it did not succeed and particularly rural development did not occur. One of the main reasons was very low level of schooling.

In order to solve illiteracy problem in rural areas, The Turkish government formed new elementary teacher training for rural areas in 1940. They were called "Village Institutions" in the history of Turkish Education (Akyüz, 2009). The education year of these schools was five years after elementary school. Those schools recruited exclusively from children in rural areas because they had lived in rural areas and had life experience about rural areas. Therefore, they would survive and stay for a while in villages and communicate with people and help them improve their economic and social life. This education policy was criticized and still has been discussed in terms of political and ideological perspectives. Particularly conservative people believe that that policy rooted in socialist philosophy. Some people believe that it was the enlightenment of Anatolia. As a result of several discussions, the Village Institutions were closed down and renamed elementary teacher training school.

This system was sustained until 1970-1971. Then, the elementary teacher schools were restructured and became seven education years three of which for middle school and four for high school. In 1973, The Basic Turkish Education Bill, which was called 1739, was enacted. According to the bill, elementary teacher training had to be increased at the higher education level. Therefore, elementary teacher training was made in two year education institutions. To be an elementary school teacher, candidates had to have two year teacher training education after graduating from high school. Those institutions were governed by The Ministry of National Education. Admissions of the institutions were controversial issue because, between 1970 and 1980, Turkish society experienced unrest and political conflict between leftists and rightists movement. In fact, all educational institutions were badly affected from this atmosphere.

Table 1

First 4: Elementary School (K-4)

\begin{tabular}{lll}
\hline GRADE & TEACHER \& COURSES & DEGREE \\
\hline $\mathrm{K}$ & Preschool teacher & Education Faculty (4 Years) \\
\hline \multirow{3}{*}{$1-2-3$} & Elementary teacher (Turkish, Knowledge of Life, Mathematics) & Education Faculty (4 Years) \\
& Visual arts & Education Faculty (4 Years) \\
& Physical education & School of Physical Education and Sports \\
& Music & Education Faculty (4 Years) \\
\hline \multirow{4}{*}{4} & Elementary teacher (Turkish,Social Studies, Science, Mathematics) & Education Faculty (4 Years) \\
& Visual arts & Education Faculty (4 Years) \\
& Physical education & School of Physical Education and Sports \\
& Music & Education Faculty (4 Years) \\
& English & Education Faculty (4 Years) \\
& Religion and Moral & Education Faculty (4 Years) \\
\hline
\end{tabular}


In 1980, Turkish Army made a coup to rule the country. Afterwards, all state agencies including educational institutions were restructured. Turkish higher education system was reformed and teacher training institutions were intergraded into university system. Between 1982 and 1992, elementary teacher training institution was renamed as the Higher School of Education and offered to associate degree because its education year was two years. Therefore, it is showed in Table 1 above that elementary teacher training program has been four years after high school. To be an elementary teacher in Turkish elementary schools is required a four year college of education degree after K-12 education.

\section{Middle School Teacher Training}

Middle school teacher training in the Turkish Education History did not exist until 1998. Teacher training between middle and high school were a subtle difference before 1982. Middle and high school had some similarities: Teachers were specialized content area instead of all subjects like elementary school. Teachers were not differentiated for middle and high school subjects. For example, history teacher was appointed to teach history, geography, and civic at the high school level or to teach social studies at the middle school level. The subtle difference was that middle school teacher was trained and recruited from three years higher teacher institution and high school teacher was trained and recruited from a faculty of literature and science. However, policy makers did not pay attention for this difference when recruiting novice teachers. Sometimes teachers were rotated from high schools to middle schools or vice versa. From 1982 to 1998, middle school teacher training did not exist and both high school teachers and middle school teachers were trained and recruited in the same way. In 1998, teacher training system was reformed and elementary, middle, and high school teacher training were differentiated in terms of subject and recruiting requirements. The Table 2 below indicates the middle school teachers' degree and higher education years. Since then, teachers' rotation from middle school to high school or vice versa has not been allowed. So middle and high school teachers are specialized in specific subject areas and teach only that subject.

Table 2

Second 4: Middle School or Religious Middle School

\begin{tabular}{lll}
\hline GRADE & TEACHER \& COURSES & DEGREE \\
\hline & Turkish & Education Faculty (4 Years) Primary Ed. \\
& Science & Education Faculty (4 Years) Primary Ed. \\
& Mathematics & Education Faculty (4 Years) Primary Ed. \\
& Social Studies (8-History and Civics) & Education Faculty (4 Years) Primary Ed. \\
& English & Education Faculty (4 Years) Primary Ed. \\
$5-6-7-8$ & Visual arts & Education Faculty (4 Years) \\
& Physical Education & School of Physical Education and Sports \\
& Music & Education Faculty (4 Years) \\
& Religious and Moral & Education Faculty (4 Years) \\
& Counseling & Education Faculty (4 Years) \\
& Designs & Education Faculty (4 Years) \\
\hline 5-6-7-8 Religious & Quran & \\
Middle School & Prophet's Life & Faculty of Theology (4 Years) \\
& Islamic Literature & \\
\hline
\end{tabular}




\section{High School Teacher Training}

Since Turkish education system is centralized, the Ministry of National Education appoints all novice teachers according to their scores in the nationwide state examination conducted by the state for state employees. Table 3 below indicates that high school teachers in Turkey are recruited from two sources; education faculty graduates, and different faculty graduates such as faculty of literature, art, science, theology, and etc. to teach particularly at high schools. A program of Education faculty takes a four year study in pedagogical preparation courses and content knowledge. Other faculty graduates must have a certification of initial teacher training program (called pedagogical formation) that takes one year. Effectiveness of this program is sometimes discussed. The implementation of teacher training programs in education faculties both in Turkey and most of European countries are almost similar. However, initial teacher training certificate program in Turkey differs from the program in European countries (notes from study visit, 2012). In some years Turkish government does not activate certificate program but recruits novice teachers to teach at high schools exclusively from education faculty graduates. In this case, other faculty graduates make a pressure on government and organize lobby activities on policy makers to activate the initial teacher training program. Since unemployment rate among university graduates is very high in Turkey, several university graduates want to be teacher in the state schools because socio-economic status of teachers in Turkey is relatively reasonable in terms of job security and income. In fact, Turkish government sometimes takes a decision in favor of education faculty graduates or other faculty graduates. There is no standard for initial teacher training for high schools in Turkey. Initial teacher training programs are influenced by current political policies. Education faculty and other faculties try to turn the advantage for themselves from the Ministry of National Education (MEB) and the Council of Higher Education (YOK).

Table 3

Third 4: High Schools

\begin{tabular}{lll}
\hline SCHOOL & COURSES & DEGREE \\
\hline & Turkish Language and Literature & \\
& Mathematics & \\
& History & \\
& Geography & EDUCATION FACULTY \\
& Geometry & 4 YEARS \\
& Composition & SCIENCE AND LITERATURE \\
SCIENCE HIGH SCHOOL & Physics & FACULTY \\
ANATOLIAN HIGH SCHOOL & Chemistry & CERTIFICATE PROGRAM \\
SEVERAL VOCATIONAL & Biology & 4 YEARS + Y YEAR \\
HIGH SCHOOLS & Philosophy & \\
& Psychology & \\
& English & \\
& Germany & \\
& Religious and Moral & EDUCATION FACULTY 4 YEARS \\
& Vocational Courses & FACULTY OF THEOLOGY \\
& & CERTIFICATE PROGRAM \\
\hline
\end{tabular}




\section{Conclusion}

The quality of teacher training in Turkey is extremely controversial issue, because before university education, each Turkish student has to take two nationwide state exams. One is for the placement in high school and second one is to get university admission. When the results of examination are publicized, first of all teachers are blamed for students' failure in rather than other factors affecting the students' success. On the other hand, Turkey has not set its own pattern for teacher training yet. Teacher training policies are affected very easily from daily politics. Although Turkey had very rich experiences and applications for teacher training, sometimes well working implementation of initial teacher training do not keep on and leave it on the middle of political discussions. Particularly initial teacher training policy for high school is changed very radically instead of moderately. Furthermore, Turkish education system is getting so huge currently. There are about seventeen million students and nine hundred thousand teachers at the K-12 level. Therefore, it is not easy to manage and sustain long term policy. Even, economic situation of the country has very close relationship with all educational reforms and policies.

\section{References}

Akyüz, Y. (2009). Türk Eğitim Tarihi: M.Ö. 1000-M.S. (The history of Turkish education: B.C. 1000 till current). Ankara: Pegem Akademi.

Caine, R. N., \& Caine, G. (2006). The way we learn. Educational Leadership, 64(1), 50-54.

Cumhuriyet Döneminde Öğretmen Yetiştirmenin Tarihi Gelişimi. (1998). Eğitim Fakülteleri Öğretmen Yetiştirme Programlarının Yeniden Düzenlenmesi İle İlgili Rapor (The report for revised and resutructured education faculty and initial teacher training, higher education council HEC). Yüksek Öğretim Kurulu Başkanlığı (YOK): Ankara.

Dursunoğlu, H. (2003) Döneminde İlköğretime Öğretmen Yetiştirmenin Tarihi Gelişimi. Retrieved 2014 September 20 from http://dhgm.meb.gov.tr/yayimlar/dergiler/Milli_Egitim_Dergisi/160/dursunoglu.htm

Kipp, H., \& Rothmann, D. (2004). Hesse-educational system-Description of the basic structure (In study visit seminar “Teachers' initial training-Recruitment and Evaluation", April 23-27, 2012. Heppenheim, Germany).

Marzano, R. J. (2003). What works in schools: Translating research into action? Alexandria, VA: ASCD Association for Supervision and Curriculum Development.

Sanders, W. L., \& Horn, S. P. (1994). The Tennessee value-added assessment system (TVASS): Mixed added assessment methodology in educational assessment. Journal of Personal Evaluation in Education, 8, 299-311.

Schere, M. (2012). Teachers under the looking glass. Educational Leadership, $70(3), 7$.

Stronge, J. H. (2002). Qualities of effective teachers. Alexandria, VA: ASCD Association for Supervision and Curriculum Development.

Vetter, G. (2012). Teacher training in Hesse - The role of the examination division (first phase of teacher education) (In study visit seminar "Teachers' initial training_Recruitment and Evaluation", April 23-27, 2012. Heppenheim, Germany). 